\title{
Use of different types of extracts as biostimulators in organic agriculture
}

\author{
Milena Đurić ${ }^{1}$, Jelena Mladenović ${ }^{1}$, Ljiljana Bošković-Rakočević1, \\ Gordana Šekularac ${ }^{1}$, Duško Brković ${ }^{1}$, Nenad Pavlović ${ }^{2}$ \\ ${ }^{1}$ University of Kragujevac, Faculty of Agronomy, Cara Dusana 34, Čačak, \\ Serbia \\ ${ }^{2}$ Institute for Vegetable Crops, Karadjordjeva 71, Smederevska Palanka, Serbia \\ Corresponding author: jelenamala@kg.ac.rs
}

\begin{abstract}
This paper presents the results of the analysis of extracts obtained from: Thymus serpyllum L., Urtica dioica L., Equisetum arvense L. and Achillea millefolium L. Extracts were subjected to the following analyses: determination of total phenols, total flavonoids and anthocyanins, and refractometric determination of soluble solids.

The results showed that the content of flavonoids was $0.4710 \mathrm{mg} / \mathrm{ml}$ in Urtica dioica extract, $0.3950 \mathrm{mg} / \mathrm{ml}$ in Equisetum arvense extract, $0.2997 \mathrm{mg} / \mathrm{ml}$ in Thymus serpyllum extract and $0.1556 \mathrm{mg} / \mathrm{ml}$ in Achillea millefolium extract. The highest content of phenolic compounds was found in Thymus serpyllum extract $(2.3583 \mathrm{mg} / \mathrm{ml})$, followed by Equisetum arvense $(2.2724 \mathrm{mg} / \mathrm{ml})$ and Urtica dioica extract $(2.1374 \mathrm{mg} / \mathrm{ml})$, and the lowest in Achillea millefolium $(1.8061 \mathrm{mg} / \mathrm{ml})$. The content of anthocyanins was highest in Urtica dioica extract $(3.966 \mathrm{mg} / \mathrm{l})$, followed by Thymus serpyllum $(3.715 \mathrm{mg} / \mathrm{l})$ and Equisetum arvense $(3.549 \mathrm{mg} / \mathrm{l})$ extracts, and lowest in Achillea millefolium extract $(0.0835 \mathrm{mg} / \mathrm{l})$. The soluble solids content was highest in Urtica dioica and Equisetum arvense $\left(2 \mathrm{BRIX} \%\right.$ at $\left.20^{\circ} \mathrm{C}\right)$, followed by Thymus serpyllum $\left(1.5 \mathrm{BRIX} \%\right.$ at $\left.20^{\circ} \mathrm{C}\right)$, and lowest in Achillea millefolium $\left(1 \mathrm{BRIX} \%\right.$ at $\left.20^{\circ} \mathrm{C}\right)$. The results showed that extracts obtained by maceration contained bioactive components; this study, therefore, provides a basis for further and deeper research on the use of these extracts as potential biostimulators in organic agriculture.
\end{abstract}

Keywords: Thymus serpyllum L., Urtica dioica L., Equisetum arvense L., Achillea millefolium L., biostimulating compounds.

Received 21 January 2019 Accepted 18 June 2019 


\section{Introduction}

Organic farming is a form of agriculture based on the use of crop rotation, green manure, compost and biological control of insects. Organic production involves the use of fertilizers and pesticides (herbicides, fungicides and insecticides) which are considered natural, whereas synthetic fertilizers and pesticides, growth regulators (hormones), antibiotics in live animals, genetically modified organisms, human sewage waste and nanomaterials are excluded or severely restricted. Due to the specific nature of organic production, in particular restrictions on the use of plant protection products, it is necessary to combine all available measures to address plant protection problems. Organic farming methods are internationally legally regulated and implemented by many countries, and are based on standards set by the International Federation of Organic Agriculture Movements, established in 1972 (http://www.serbiaorganica.info/organska-poljoprivreda).

The market for organic food and other organic products has been rising rapidly since 1990, reaching a value of 63 billion dollars in 2012. Such requests have led to an increase in areas where organic production principles are applied. This growth from 2001 to 2011 is around $8.9 \%$ per year. Organic production in 2011 was applied to approximately 37 million hectares, accounting for about $0.9 \%$ of world arable land. Organic production in the Republic of Serbia is increasingly popular and economically significant. Thanks to potentials that are reflected in fragmented land and non-contaminated soil, this type of agriculture encourages the consumption of healthy food within the region, creates a basis for the development of ecotourism, reduces production costs and significantly contributes to the preservation of the socio-cultural heritage of rural areas. A constant tendency towards increasing yields has led to soil degradation, environmental pollution and health-related unsafe food.

The production of medicinal herbs is accompanied by a range of problems, such as lack of organization, fragmentation of programs, lack of equipment, a gap between science and practice, a limited number of cultivated species, unsuitable varieties, small variable yields, insufficient quality, undeveloped market. Today, the situation is gradually changing. Many of the problems have been overcome, and the structure of medicinal herb production has been significantly improved. New varieties are being introduced and the results of scientific research have been increasingly used. The number of commodity producers is increasing both in the social and the private sector, with the cultivation of medicinal herbs as their only or main interest. Production is specialized or concentrated in certain farms, where it assumes the character of their main economic activity. This production is expanding, resulting in an increased breeders' interest in learning new methods and ways of improving the production. The use of synthetic preparations is not permitted; therefore, in practice, "domestic" natural pesticides are increasingly used, and manufacturers 
often independently produce proven and effective alternative pesticides (Vlahović and Puškarić, 2013). In recent years, interest in essential oils as possible substitutes for conventional synthetic pesticides has been growing (Oljača, 2012). In organic agriculture, many medicinal and herbal plants have multiple roles.

Biostimulants are substances that improve the immune system of cultivated plants and positively affect their metabolism (Kolomaznik et al., 2012), and can be applied at different stages of plant growth and development (Tkalec et al., 2010). They may contain: humic acids, hormones, amino acids and other physiologically active substances (vitamins, polysaccharides, etc.), individually or in combination (Zeljković, 2013). Biostimulators reduce stress under unfavorable temperatures, increase yield, reduce harmful consequences in the event of drought, freezing, mechanical and chemical damage, as well as in cases of viral plant infection (Maini, 2006). Also, they are often used to treat seed before sowing (Jankauskiene and Surviliene, 2009). Biostimulators (plant hormones, vitamins, etc.) stimulate seed germination, especially under stressful conditions (Záborsky et al., 2002). Also, they drive the biological activity of plants, simultaneously acting on the plant, root and soil microflora (Jelačić et al., 2006).

Nettle (Urtica dioica) is a herbaceous perennial plant. Some species have been used in folk medicine since ancient times for exceptional medicinal properties. Nettle grows on terrains rich in nitrogen, and reaches a height of up to one meter at the flowering stage. Products based on nettle extract are rich in nitrogen (phytostimulants) and promote the growth of cultivated plants. Also, they contain plenty of oligoelements, which work well on leaves, and are also used as acaricides against the red spider. Nettle extract also has a repelling effect on many other insects. A thick nettle solution is used as a fungicide and repellant. Nettle has an unpleasant smell and repels mites from leaves, thus controlling brown rot. For its preparation, only apical parts of the nettle are used - one kilogram of the plant is immersed in 10 liters of water and allowed to stand for 10 to 15 days in the shade (preferably at about $18^{\circ} \mathrm{C}$ ). The solution will thicken and turn brown. It is ready for use when air bubbles are no longer generated at the surface. It is best to use it in the vegetation growth period, every three weeks. Before use, the solution is diluted with water in a ratio of 1:7 and poured into a sprayer to treat plants and the surrounding area. It is necessary to leave it in a dark place in a sealed container for up to 12 months. For a solution against the celery flies, $224 \mathrm{~g}$ of young nettle plants should be soaked in water for a week, then processed and the concentrated solution is ready for use. It can be used on vegetables and fruits. It repels some types of insects, and at the same time strengthens the plant through foliar savings. Nettle positively affects the growth and reproduction of a large number of crops when grown at 1:100 in relation to the main crop. Also, some insects (carrot fly) will rather feed on nettle than carrots, and in this way nettle protects the crop. Freshly harvested nettle can be 
put into kitchen cabinets to repel flies and moths. In order to be used as a spray solution, chopped nettle is covered with cold water and left to stand for two days. Then, plants are sprayed with a 5\% solution of the liquid obtained. The macerate is used to suppress aphids. It also works against some plant diseases. Nettle plants can be macerated, allowed to stand for 4 days and added to the macerate from Equisetum arvense at a ratio of 1:1.5, and then $20 \mathrm{~L}$ of water is added. It can be applied to the leaves of plants attacked by the red spider. If $1 \mathrm{~kg}$ of sugar is added to these 20 liters along with 1\% of macerate from the Marsiglia migliore extract, it acts curatively against some crop diseases.

The yarrow (Achillea millefolium) is widespread and grows along the edges of arable land, in sunny slopes, pastures, along roads and paths. If the soil is poor in nutrients, yarrow can serve as an indication of the lack of nitrogen and other nutrients in the soil. It can also be grown in plantations because it is not a demanding plant. In the same plot, it can be grown for up to 5 years. It is a perennial plant whose root is rising with rice. It has a pleasant smell, and it flashes from June to October. It is being read in full bloom during June, July and part of August. A flower with a stem of up to $15 \mathrm{~cm}$ in length or only a flower with a stem length of $2 \mathrm{~cm}$ is read. Haywood grass is dried connected in small buckets on a swing or in dryers. Dry plants have an extremely aromatic fragrance. They are stored in paper bags and cardboard boxes, in dry and cold rooms, protected from light for about 1.5 years. In addition to its medicinal properties, yarrow is often used for herbal preparations in organic agriculture. The plant in the garden attracts insect pollinators, primarily bees and bumblebees. It is a natural repellant, which repels ants, bugs, flies and mosquitoes.

Equisetum arvense is a perennial plant with a thin horizontal root. The permanent underground part of the stem is black in color and, like a thread, it extends into depth and width. It is very resistant. It contains alkaloids, flavonoids, glycosides, carotene, vitamin $\mathrm{C}$, organic acids, tannins, resins and macro- and microelements. The field horsetail has fungicidal properties. Tea from the diet is very important in organic production because it acts against several fungal diseases (ashtrays, mushroom, leaf rust, dander). Preparations are made from 1 $\mathrm{kg}$ of dry or $3 \mathrm{~kg}$ of fresh plants. Harvest should be done in the morning and plants should be dried in the shade to preserve color and odor. The plants are put in cold water and cooked for up to 20 minutes in 20 liters of water. The resulting product is processed and 80 liters of water is added to the solution, and then the plants are treated. The plant, like nettle, can also be used to protect crops. Three $\mathrm{kg}$ of fresh plants are immersed in 100 liters of water and allowed to ferment for twenty days. When fermentation stops (there is no new foam), the preparation is processed, and 300 liters of water are added to the resulting solution and watered by the plants. The resulting liquid can also be used to dissolve potassium soap in the process of suppressing plant and chaff. 
Wild thyme (Thymus serpyllum) is a herbaceous perennial plant with a oneyear herbaceous tree. The root is perennial, very branched, with a plethora of small veins. The whole plant has a pleasant smell and taste. The fragrance is intense, especially at the time of flowering. It blooms from May to September.

\section{Material and methods}

Four spice and medicinal plants served as the subject of the research, i.e. wild thyme (Thymus serpyllum); nettle (Urtica dioica); field horsetail (Equisetum arvense) and yarrow (Achillea millefolium).

The following analyses were performed:

-preparation of macerates and determination of the contents of total flavonoids, total phenols, total anthocyanins and soluble solids.

-Preparation of macerates: Already triturated plant material $(20 \mathrm{~g})$ is covered with a solvent ( $200 \mathrm{ml}$ per liter of distilled water) and protected from the sunlight with aluminum foil. The maceration was carried out for 2 hours with occasional stirring at room temperature. After two hours, the plant material from the macerate was separated by filtering through filter paper (a black strip). The solvent was removed by evaporation in an aqueous bath, and the resulting extract was dried to dryness (dry extract weight was not measured, and therefore the yield was not calculated).

-Determination of total flavonoid content: The method is based on the ability of flavonoids to complex with metal cations (such as $\mathrm{Al}^{3+}$ ) forming chelates (Figure 1). Delocalization and movement of UV and VIS absorption strips by about $50 \mathrm{~nm}$ to higher wavelengths (achromatic effect), i.e. the color of the solution turns from yellow to yellow-green or more intense yellow.

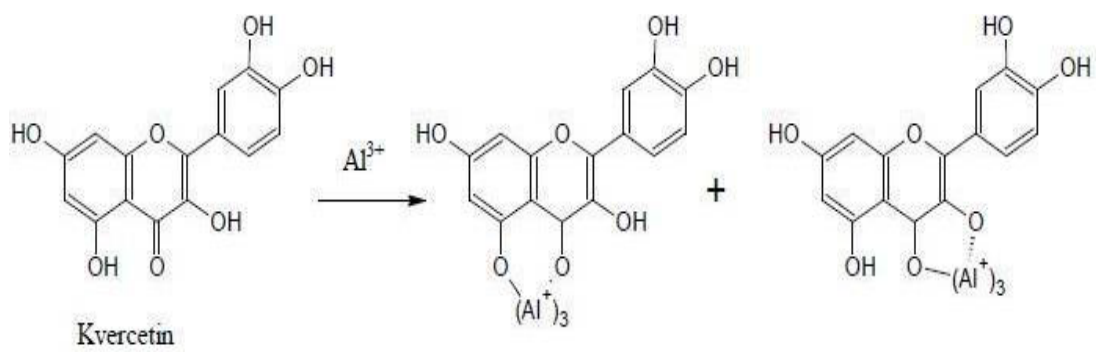

Figure 1. Construction of the flavonoid chelate with $\mathrm{Al}^{3+}$ jon

\section{Reagents:}

Rutin solution was made as follows: $0.1 \mathrm{~g}$ of rutin was dissolved in distilled water in a $50 \mathrm{ml}$ beaker. The solute content was quantitatively transferred to a measuring vessel of $100 \mathrm{ml}$ by means of a funnel. A $50 \mathrm{ml}$ glass was washed with distilled water and after washing the contents of the beaker were again 
transferred to a $100 \mathrm{ml}$ measuring vessel. By adding the measuring vessel to the line, the concentration of the parent solution (m) of rutin is $1 \mathrm{mg} / \mathrm{ml}$. Five standard solutions of the above concentrations were prepared, and absorbance was measured spectrophotometrically for each concentration at $\lambda=430 \mathrm{~nm}$. Then, a plot of absorbance vs. concentration was drawn. In this way, the calibration diagram of rutin was used to determine flavonoids (Figure 2).

Determination of total phenols was determined by the Folin-Ciocalteu method. The method is based on the color reaction of phenol with FolinCiocalteu reagent. Folin-Ciocalteu reagent is a mixture of blue-colored phosphonoframine and phosphomolybdic acid, which are reduced to tungsten oxide and molybdenum oxide during the oxidation of the phenolic compounds (Ough and Amerine, 1988). Five standard solutions of the above concentrations were prepared and absorbance measured spectrophotometrically for each concentration at $\lambda=765 \mathrm{~nm}$. Then, absorbance was plotted against concentration. In this way, a glycolic acid calibration diagram was obtained for the determination of total phenols (Figure 3).

For the determination of total anthocyanins, the extracts were prepared by maceration. The procedure involved grinding of the plant material $(20 \mathrm{~g})$, extracted with a solvent ( $200 \mathrm{ml}$ of distilled water) and stored in flasks protected from sunlight with aluminum foil. The next step is macerate filtration and the solvent was removed by evaporation in a water bath. After evaporation, the residue was poured into a standing vial and dried to constant weight. As dry extract weight was not taken, yield was not calculated. Extract solutions were made by $0.1 \mathrm{~g}$ of the extract dissolved in distilled water in a $100 \mathrm{ml}$ vessel. By adding to the line, an extract concentration of $1 \mathrm{mg} / \mathrm{ml}$ was obtained.

The determination of the total anthocyanin content was based on the $\mathrm{pH}$ diffraction method. The process was carried out by measuring $1 \mathrm{ml}$ of extract which was quantitatively transferred to a $25 \mathrm{ml}$ measuring vessel. The measuring vessel should be supplemented to a measuring line with buffer $\mathrm{pH}=1.0$. Another $1 \mathrm{ml}$ extract was added to another $25 \mathrm{ml}$ measuring vessel, and buffer $\mathrm{pH}=4.5$ was added to line. The solutions were allowed to stabilize for 15 minutes. The determination was performed spectrophotometrically by measuring the absorbance of the prepared solutions at wavelengths of 510 and $700 \mathrm{~nm}$. Based on the measured absorbances and using the equations below, the content of total anthocyanins was determined:

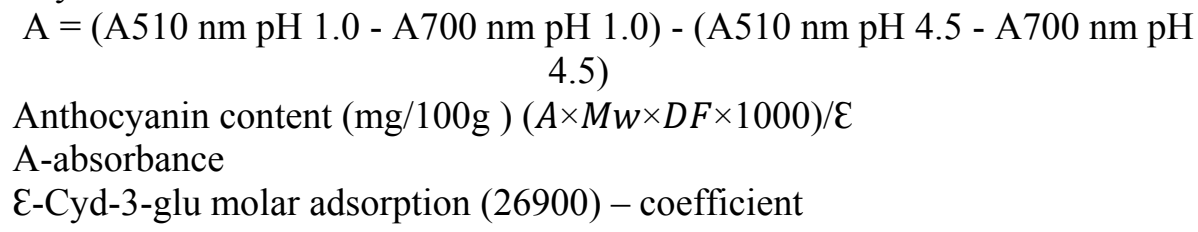


DF-dilution factor (in our case it is 25 , since $1 \mathrm{ml}$ of the extract was diluted 25 times in buffer).

Refractometric determination of soluble solids

Principle of determination: Taking soluble solids readings directly from the scale on a handheld refractometer.

Determination procedure: A drop of test extract is placed between two prisms, and the device is directed towards the light source. The handheld refractometer has an eyepiece, where a visible field with a scale is immediately visible. It is necessary to determine the scale and the boundary between the light and the dark field. The upper scale shows BRIX $(1 \mathrm{~g} / 100 \mathrm{~g})$, while readings are taken from the lower scale.

\section{Results and discussion}

The content of flavonoids in plant extracts is greatly influenced by planting conditions, plant treatments, UV radiation and the concentration of $\mathrm{SO} 2$, but the content and composition of flavonoids is primarily genetically conditioned. Spectrophotometry was used to determine total flavonoids in aqueous extracts (macerates) of the tested plants. The absorbances of the previously made concentrations of rutin standards were spectrophotometrically measured at 430 $\mathrm{nm}$ :

1. for $0.01 \mathrm{mg} / \mathrm{ml}$ solution, the absorbance was 0.006 ;

2. for $0.05 \mathrm{mg} / \mathrm{ml}$ solution, the absorbance was 0.014 ;

3. for $0.1 \mathrm{mg} / \mathrm{ml}$ solution, the absorbance was 0.041 ;

4. for $0.25 \mathrm{mg} / \mathrm{ml}$ solution, the absorbance was 0.108 ; and

5. for $0.5 \mathrm{mg} / \mathrm{ml}$ solution, the absorbance was 0.202 .

Based on the measured absorbances, using the calibration curve of the standard rutin solution (Figure 2$)$, the concentrations $(\mathrm{mg} / \mathrm{ml})$ of flavonoids were obtained. 


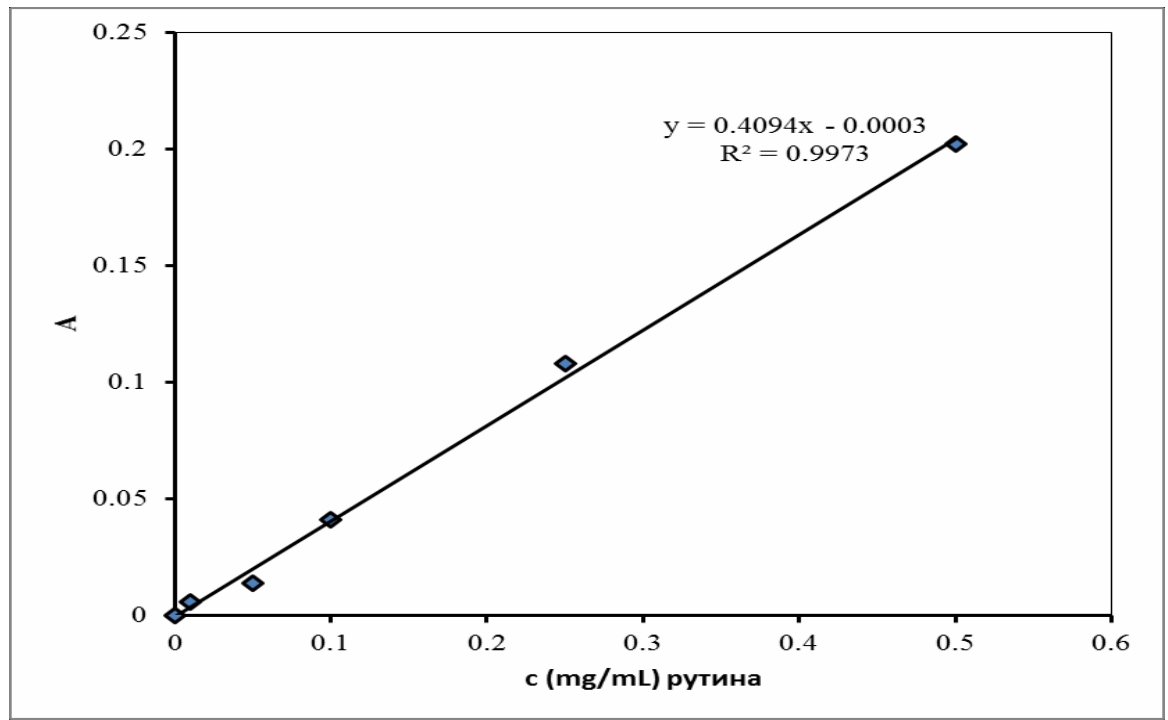

Figure 2. Calibration curve of rutin

The contents of flavonoids for the tested extracts, which were determined on the basis of the standard rutin curve, are given in Table 1.

Table 1. The contents of flavonoids in the tested extracts

\begin{tabular}{|c|c|c|}
\hline Extract & Absorbance & Concentration $(\mathrm{mg} / \mathrm{ml})$ \\
\hline Achillea millefolium L. & 0.064 & 0.1556 \\
\hline Thymus serpyllum L. & 0.123 & 0.2997 \\
\hline Equisetum arvense L. & 0.162 & 0.3950 \\
\hline Urtica dioica L. & 0.196 & 0.4710 \\
\hline
\end{tabular}

The contents of total phenols were determined by the Folin-Ciocalteu method, and phenolic compounds in the macerate extracts were determined based on the calibration diagram of the standard gallic acid.

The following absorbances of various concentrations of gallic acid standards were measured at $765 \mathrm{~nm}$ :

1. for $0.05 \mathrm{mg} / \mathrm{ml}$ solution, the absorbance was 0.002 ;

2. for $0.1 \mathrm{mg} / \mathrm{ml}$ solution, the absorbance was 0.007 ;

3. for $0.25 \mathrm{mg} / \mathrm{ml}$ solution, the absorbance was 0.028 ;

4. for $1 \mathrm{mg} / \mathrm{ml}$ solution, the absorbance was 0.089 ;

5. for $2.5 \mathrm{mg} / \mathrm{ml}$ solution, the absorbance was 0.203 . 
Based on the calibration diagram of standard gallic acid, the content of phenolic compounds in the examined extracts was determined (Figure 3).

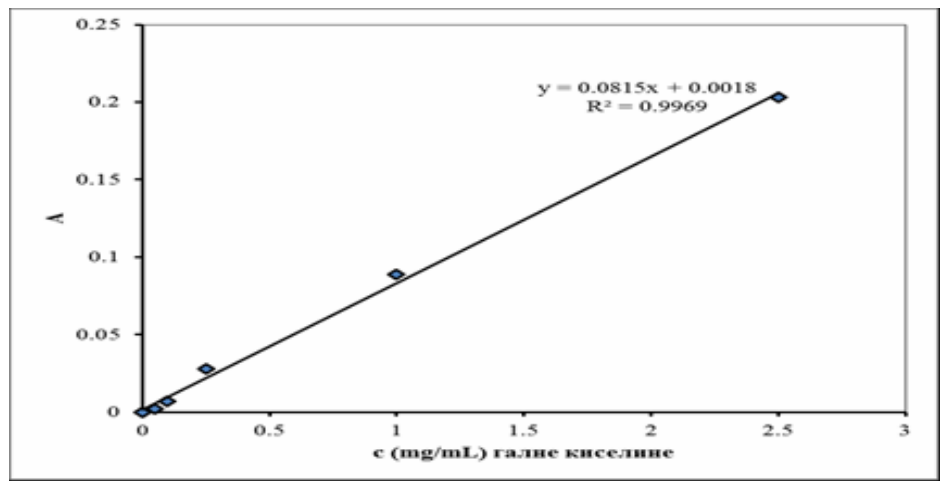

Figure 3. Gallic acid calibration diagram

The results on the content of phenolic compounds are given in Table 2 .

Table 2. The concentrations of phenolic compounds

\begin{tabular}{|c|c|c|}
\hline Extract & Absorbance & Concentration $(\mathrm{mg} / \mathrm{ml})$ \\
\hline Achillea millefolium L. & 0.149 & 1.8061 \\
\hline Thymus serpyllum L. & 0.194 & 2.3583 \\
\hline Equisetum arvense L. & 0.187 & 2.2724 \\
\hline Urtica dioica L. & 0.176 & 2.1374 \\
\hline
\end{tabular}

The results show that the highest content of phenolic compounds was determined in wild thyme $(2.3583 \mathrm{mg} / \mathrm{ml})$, followed by field horsetail $(2.2724$ $\mathrm{mg} / \mathrm{ml})$ and nettle $(2.1374 \mathrm{mg} / \mathrm{ml})$, while the lowest content was obtained in yarrow $(1.8061 \mathrm{mg} / \mathrm{ml})$.

The obtained liquid extracts can be used both for foliar treatments and for water treatment. Since biostimulants are based on plant extracts rich in bioactive compounds and do not have harmful effects on human health, there is a need for further research into their mechanism of action, in particular regarding the final quality of plant products. The extracts obtained by maceration in this research contain bioactive components, and thus this paper provides the basis for further and deeper research on their use as potential biostimulators. 
The contents of total anthocyanins

Table 3. Absorbance values for the contents of total anthocyanins

\begin{tabular}{|c|c|c|c|}
\hline \multirow{2}{*}{ Extract } & \multirow{2}{*}{ Buffer } & \multicolumn{2}{|c|}{ Absorbance values at wavelengths } \\
\cline { 2 - 4 } & & $510 \mathrm{~nm}$ & $700 \mathrm{~nm}$ \\
\hline \multirow{2}{*}{ Equisetum arvense L. } & $\mathrm{pH} 1.0$ & 0.0355 & 0.0459 \\
\cline { 2 - 4 } & $\mathrm{pH} 4.5$ & 0.0220 & 0.0409 \\
\hline \multirow{2}{*}{ Urtica dioica $\mathrm{L}}$. & $\mathrm{pH} 1.0$ & 0.0509 & 0.0077 \\
\cline { 2 - 4 } & $\mathrm{pH} 4.5$ & 0.0554 & 0.0217 \\
\hline \multirow{2}{*}{ Thymus serpyllum L. } & $\mathrm{pH} 1.0$ & 0.0635 & 0.0237 \\
\cline { 2 - 4 } & $\mathrm{pH} 4.5$ & 0.0458 & 0.0149 \\
\hline \multirow{2}{*}{ Achillea millefolium L. } & $\mathrm{pH} 1.0$ & 0.0095 & 0.0018 \\
\cline { 2 - 4 } & $\mathrm{pH} \mathrm{4.5}$ & 0.0093 & 0.0018 \\
\hline
\end{tabular}

Based on the measured absorption of the prepared solutions at 510 and 700 $\mathrm{nm}$ wavelengths (Table 3), and the equations for determining the content of total anthocyanins, the highest contents of anthocyanins were found in extracts from nettle $(3.966 \mathrm{mg} / \mathrm{l})$, followed by thyme $(3.715 \mathrm{mg} / \mathrm{l})$ and field horsetail $(3.549$ $\mathrm{mg} / \mathrm{l})$, and the lowest in yarrow $(0.0835 \mathrm{mg} / \mathrm{l})$.

The contents of soluble solids determined by refractometry

The contents of soluble solids are expressed in BRIX units. 1 BRIX $=1 \mathrm{~g}$ soluble solids per $100 \mathrm{~g}$ of solution.

Table 4. Values of Soluble Solids

\begin{tabular}{|c|c|}
\hline Extract & $\begin{array}{c}\text { Soluble solids } \\
\left(\mathrm{BRIX} \% \text { at } 20^{\circ} \mathrm{C}\right)\end{array}$ \\
\hline Urtica dioica $\mathrm{L}$. & 2.0 \\
\hline Thymus serpyllum $\mathrm{L}$. & 1.5 \\
\hline Achillea millefolium $\mathrm{L}$. & 1.0 \\
\hline Equisetum arvense $\mathrm{L}$. & 2.0 \\
\hline
\end{tabular}

The soluble solids content was the highest in nettle $\left(2 \mathrm{BRIX} \%\right.$ at $\left.20^{\circ} \mathrm{C}\right)$ and field horsetail $\left(2 \mathrm{BRIX} \%\right.$ at $\left.20^{\circ} \mathrm{C}\right)$, and the lowest in yarrow $\left(1 \mathrm{BRIX} \%\right.$ at $\left.20^{\circ} \mathrm{C}\right)$. Soluble solids were mainly carbohydrates and sugars.

\section{Conclusion}

The experimental results of this research showed the following: 
- the highest content of flavonoids was determined in extracts from nettle $(0.4794 \mathrm{mg} / \mathrm{ml})$, followed by field horsetail $(0.3964 \mathrm{mg} / \mathrm{ml})$ and thyme $(0.3011$ $\mathrm{mg} / \mathrm{ml})$, and the lowest in yarrow $(0.1570 \mathrm{mg} / \mathrm{ml})$;

- the highest content of phenolic compounds was determined in thyme $(2.3632 \mathrm{mg} / \mathrm{ml})$, followed by field horsetail $(2.2760 \mathrm{mg} / \mathrm{ml})$ and nettle $(2.1325$ $\mathrm{mg} / \mathrm{ml})$, and the lowest in yarrow $(1.8049 \mathrm{mg} / \mathrm{ml})$;

- The highest content of anthocyanins was determined in extracts from nettle $(3.966 \mathrm{mg} / 1)$, followed by thyme $(3.715 \mathrm{mg} / \mathrm{l})$ and field horsetail $(3.549 \mathrm{mg} / 1)$, and the lowest in yarrow $(0.0835 \mathrm{mg} / \mathrm{l})$;

- The soluble solids content, determined by a handheld refractometer, was highest in nettle $\left(2 \mathrm{BRIX} \%\right.$ at $\left.20^{\circ} \mathrm{C}\right)$ and field horsetail $\left(2 \mathrm{BRIX} \%\right.$ at $\left.20^{\circ} \mathrm{C}\right)$.

The results indicate that the extracts can be used as very good biostimulators. Global requirements to reduce the use of chemical pesticides which are considered harmful to consumers govern the development and further research on extracts from various plant species as useful biostimulators to obtain quality organic products. These studies require deeper and more detailed analysis.

\section{Acknowledgments}

This study was supported by the Serbian Ministry of Education, Science and Technological Development: Project No. TR 31059.

\section{References}

Jankauskiene J., Surviliene E. (2009): Influence of growth on seed germination energy and biometrical parameters of vegetables. Science Works of the Lithuanian Institute of Horticultrae and Lithuanian University of Agricultural, 29 (3): 69-77.

Jelačić S., Beatović D., Vujošević A., Lakić N. (2006): Uticaj prirodnih biostimulatora ispororazlagajućih đubriva na kvalitet rasada bosiljka (Ocimum basilicum L.) i matičnjaka (Melissa officinnnnalis L.)“, Poljoprivredna tehnika, 4: 117-123.

Kolomaznik K., Pecha J., Friebrovà V., Janàčovà D., Vašek V. (2012): Diffusion of biostimulators into plant tissues. Heat and Mass Transfer, 48: 1505- 1512.

Maini P. (2006): The experience of the first biostimulant, based on amin oacids and peptides:a short retrospective review on the laboratory researches and the practical results. Centro Scientifico Italiano dei Fertilizzanti, Fertilitas Agrorum, 1: 29-43.

Oljača S. (2012): Organska poljoprivredna proizvodnja, Zadužbina Adrejević, Beograd.

Ough C.S., Amerine M.A. (1988): Methods for analysis of musts and wines. Secon edition, Johan Wiley \& sons, New York, Chichester, Brisbane, Toronto, Singapore.

Tkalec M., Vinković T., Baličević R., Parađiković N. (2010): Uticaj biostimulatora na rast i razvoj paprike (Capsicum annuum L.). Acta agriculturae Serbica, 15: 83-88.

Vlahović B., Puškarić A. (2013): Priručnik Organska poljoprivreda - Šansa za agrobiznis, Novi Sad. 
Zeljković S. (2013): Primjena biostimulatora u proizvodnji begonije (Begonija semperflorens Link.et Otto) i kadifice (Tagetes patula L.)", Doktorska disertacija. Poljoprivredni fakultet Univerziteta u Novom Sadu.

Záborsky S., Nagy E., Szöke C. (2002): Effect of seed treatment on the emergence of inbred lines in maize (Zea maysL.). Acta Agronomica Hungarica, 50: 359-369

http://www.serbiaorganica.info/organska-poljoprivreda/ 
Acta Agriculturae Serbica, Vol. XXIV, 47(2019); 27-39

\title{
KORIŠĆENJE RAZLIČITIH TIPOVA EKSTRAKATA KAO BIOSTIMULATORA U ORGANSKOJ POLJOPRIVREDI
}

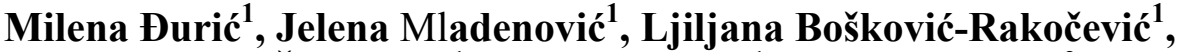 \\ Gordana Šekularac ${ }^{1}$, Duško Brković ${ }^{1}$, Nenad Pavlović ${ }^{2}$ \\ ${ }^{1}$ Univerzitet u Kragujevcu, Agronomski fakultet u Čačku, Cara Dušana 34, \\ Čačak, Srbija \\ ${ }^{2}$ Institut za povrtarstvo, Karađorđeva 71, Smederevska Palanka, Srbija
}

\section{Rezime}

Ovaj rad prezentuje rezulate analize ekstrakata dobijenih od: Thymus serpyllum L., Urtica dioica L., Equisetum arvense L. i Achillea millefolium L. Na ekstraktima su rađene sledeće analize: određivanje ukupnih fenola, flavonoida i antocijana, kao i refraktometrijsko određivanje rastvorljivih materija. Rezultati su pokazali da je koncentracija flavonoida bila $0.4710 \mathrm{mg} / \mathrm{ml}$ in ekstraktu Urtica dioica, $0.3950 \mathrm{mg} / \mathrm{ml} \mathrm{u}$ ekstraktu Equisetum arvense, $0.2997 \mathrm{mg} / \mathrm{ml}$ in ekstraktu Thymus serpyllum i $0.1556 \mathrm{mg} / \mathrm{ml} \mathrm{u}$ ekstraktu Achillea millefolium. Najveći sadržaj fenolnih komponenti je pronađen u ekstraktu Thymus serpyllum (2.3583 $\mathrm{mg} / \mathrm{ml})$, zatim u ekstraktima Equisetum arvense $(2.2724 \mathrm{mg} / \mathrm{ml})$ i Urtica dioica $(2.1374 \mathrm{mg} / \mathrm{ml})$, a najniži u Achillea millefolium $(1.8061 \mathrm{mg} / \mathrm{ml})$. Najveći sadržaj antocijana je pranađen u ekstraktu Urtica dioica $(3.966 \mathrm{mg} / \mathrm{l})$, zatim u ekstraktima Thymus serpyllum $(3.715 \mathrm{mg} / \mathrm{l})$ i Equisetum arvense $(3.549 \mathrm{mg} / \mathrm{l})$, a najniži u ekstarktu Achillea millefolium $(0.0835 \mathrm{mg} / \mathrm{l})$. Najveći sadržaj rastvorljivih materija je zabeležen u Urtica dioica i Equisetum arvense (2 BRIX\% na $20^{\circ} \mathrm{C}$ ), zatim u Thymus serpyllum (1.5 BRIX\% na $\left.20^{\circ} \mathrm{C}\right)$, a najniži kod Achillea millefolium (1 BRIX\% na $20^{\circ} \mathrm{C}$ ). Rezultati su pokazali da ektsrakti dobijeni maceracijom sadže bioaktivne komponente, tako da ovaj rad pruža osnovu za dalje i dublje istraživanje upotrebe ovih ekstrakata kao potencijalnih biostimulatora u organskoj poljoprivredi.

Ključne reči: Thymus serpyllum L., Urtica dioica L., Equisetum arvense L., Achillea millefolium L., biostimulatori. 